\title{
Popularyzacja zasobu Archiwum Narodowego w Krakowie w roku jubileuszowym stulecia Archiwów Państwowych - podsumowanie
}

Rok 2019 był dla Archiwów Państwowych rokiem szczególnie ważnym. Obchody jubileuszu stulecia ich powstania przyczyniły się do podkreślenia znaczenia archiwów i pokazania jednolitej polityki archiwalnej scalającej różne tradycje ukształtowane na ziemiach polskich w okresie zaborów. O randze, jaką dla naszego narodu ma ich dziedzictwo dokumentacyjne, dobitnie świadczy fakt, iż już w pierwszych miesiącach istnienia odbudowanej Polski, 7 lutego 1919 r., Naczelnik Państwa Józef Piłsudski podpisał Dekret o organizacji archiwów państwowych i opiece nad archiwaliami stanowiący fundament budowy administracji nowo powstałego państwa. Już wiek temu, zgodnie z postanowieniami tego aktu, jednolita struktura organizacyjna obejmowała zarówno archiwa powstałe na ziemiach polskich w XIX i na początku XX w., jak i nowe utworzone w II Rzeczypospolitej. 1 października 1919 r. istniejące od 1878 r. Krajowe Archiwum Akt Grodzkich i Ziemskich w Krakowie również włączono w struktury sieci polskich archiwów państwowych. Od tego czasu krakowskie Archiwum pozostało w tych strukturach, kilkakrotnie zmieniało swoją organizację i nazwę, aż do obecnej nadanej mu przez Ministra Kultury i Dziedzictwa Narodowego w 2012 r.

Podobnie jak w całej sieci archiwów państwowych również w naszej instytucji cały rok 2019 upłynął pod znakiem obchodów jubileuszowych. Logo stulecia Archiwów Państwowych towarzyszyło niemal wszystkim wydarzeniom organizowanym w krakowskim Archiwum. Identyfikacja wizualna obchodów rocznicowych została wprowadzona w internecie jako wizytówka instytucji, a także na publikacjach książkowych czy drukach reklamowych organizowanych wydarzeń. Archiwum Narodowe w Krakowie i jego oddziały zamiejscowe, podobnie jak inne archiwa, wprowadziły na blankietach korespondencyjnych logotyp informujący o obchodach rocznicowych.

Już w 2018 r. z myślą o nadchodzącym jubileuszu wydano publikację autorstwa dr Moniki Andrasz-Mrożek Krakowskie Archiwum 1878-1952. Od Krajowego do Państwowego. Zaś w dniu 7 lutego 2019 r. w 100. rocznicę podpisania Dekretu o archiwach opublikowano film dokumentalny zatytułowany „Od Krajowego do Państwowego” przypominający o historii naszej instytucji - dostępny na kanale YouTube pod linkiem https://www.youtube. com/watch?v=k-V_tTyVlwU\&t=371s, (scenariusz Lilianna Pochwalska).

Archiwum Narodowe w Krakowie wpisało się w obchody stulecia Archiwów Państwowych jako organizator i współorganizator wystaw, projektów edukacyjnych oraz wydawnictw popularyzujących bogate zbiory archiwalne. Pod hasłem obchodów jubileuszowych zorganizowano m.in.: XII Międzynarodowy Dzień Archiwów w dniu 8 czerwca 2019 r. poświęcony tym razem promocji najcenniejszych obiektów w zasobie Archiwum Narodowego w Krakowie oraz prezentacji nowej odsłony portalu www.szukajwarchiwach.gov. pl. Podczas dnia otwartego pokazano trzy oryginalne XIV-wieczne archiwalia zaliczane 
do najcenniejszych i najciekawszych w zasobie (najstarszą zachowaną księgę miejską krakowską, obejmującą zapiski z lat 1300-1375, XIV-wieczną pieczęć majestatyczną króla polskiego Kazimierza Wielkiego oraz dokument Jadwigi Andegaweńskiej z 1385 r. opatrzony unikatową pieczęcią majestatyczną królowej). Dla uczestników dnia otwartego przygotowano także pokaz mało znanych fotografii dawnego Krakowa (dr Barbara Zbroja), prezentację na temat 29 najcenniejszych i najciekawszych obiektów z zasobu Archiwum (Lilianna Pochwalska), zaś na dziedzińcu wewnętrznym otwarto Plenerowe Laboratorium Archiwalne, gdzie „brano pod lupę” i omawiano wymienione wcześniej oryginalne obiekty (Bożena Lesiak-Przybył, Anna Sokół, Aldona Warzecha). Przygotowano również materiały promocyjne i informacyjne (dr Barbara Berska).

W 2019 r. Naczelny Dyrektor Archiwów Państwowych ustanowił „Dzień Archiwisty” przypadający na 30 września, kiedy wspominany jest św. Hieronim ze Strydonu, patron bibliotekarzy i archiwistów. Z tej okazji zorganizowano w budynku przy ul. Siennej 16 cztery tury warsztatów „Zostań rodzinnym archiwistą”, podczas których przedstawiono za pomocą prezentacji multimedialnych informacje na temat porządkowania, przechowywania i zabezpieczania rodzinnych archiwaliów i pamiątek (Małgorzata Bochenek, Tomasz Wroński). Projekt pokazano również w Centrum Kultury Podgórza - Dwór Czeczów, w trakcie spotkania promocyjnego wydawnictwa Udział mieszkańców Bieżanowa w walce o niepodległość Polski (1914-1920) (autor Tomasz Wroński).

Jak każdej jesieni w centrali Archiwum odbyły się spotkania edukacyjne poświęcone historii Krakowa, prowadzone przez rzecznika prasowego Towarzystwa Miłośników Historii i Zabytków Krakowa - Konrada Myślika. Bogatą ofertę wydarzeń edukacyjnych uzupełniły spotkania warsztatowe i wykłady w ramach II edycji projektu „Halo tu Archiwum!” w dniach 21 listopada - 12 grudnia 2019 r. przeprowadzone w sześciu miejscowościach: Kraków, Nowy Sącz, Bochnia, Nowy Targ, Tarnów i Spytkowice (Anna Sokół i Aldona Warzecha przy udziale pracowników Archiwum). Działania edukacyjne podejmowane przez Archiwum Narodowe w Krakowie dopełniały liczne lekcje i pokazy archiwalne organizowane w ciągu całego roku jubileuszowego.

W 2019 r. podpisano 15 umów i porozumień o współpracy w zakresie popularyzacji zasobu, dzięki którym coraz szerzej promowano zasób krakowskiego Archiwum. Właśnie w wyniku takiej współpracy z Towarzystwem Miłośników Historii i Zabytków Krakowa oraz władzami miasta powstała wystawa plenerowa „650 lat herbu miasta Krakowa" dedykowana prof. Marianowi Friedbergowi, prezentowana w październiku na placu Szczepańskim w Krakowie, a następnie na dziedzińcu Archiwum (Bożena Lesiak-Przybył, Aldona Warzecha, dr hab. prof. UJ Zenon Piech). W roku jubileuszowym zorganizowano samodzielnie lub w ramach współpracy partnerskiej osiem wystaw tradycyjnych: m.in. „Sądecczyzna w materiałach archiwalnych Archiwum Narodowego w Krakowie” (wystawa stała w oddziale nowosądeckim ANK); „,Tożsamość. 100 lat polskiej architektury 1918-1939" (wystawa przygotowana przez Narodowy Instytut Architektury i Urbanistyki w Warszawie); „W rzeczach wielkich wystarczy chcieć - historia powstania Akademii Górniczej” (wystawa przygotowana przez Akademię Górniczo-Hutniczą im. Stanisława Staszica w Krakowie); „Kombinat formy - przestrzenie Huty im. Lenina na fotografiach z lat 1950-1960” (wystawa zorganizowana przez Ośrodek KARTA); „A więc Wojna! wspomnienie 1 września 1939" (wystawa przygotowana we współpracy ze Starostwem Po- 
wiatowym w Bochni). Archiwum i jego oddziały zamiejscowe włączyły się również w organizację takich wydarzeń, jak: Narodowy Dzień Żołnierzy Wyklętych, Ogólnopolski konkurs inicjatyw samorządowych uczestników OHP „Aktywność - dobry wybór” - praca na rzecz zasobu archiwalnego, Galicyjskie źródła niepodległości Ukrainy i Polski, Weekend z zabytkami powiatu bocheńskiego w ramach Europejskich Dni Dziedzictwa, Gra Miejska - Bochnia pod okupacją niemiecką.

19 października w Hotelu Polonia miała miejsce uroczystość przekazania w darze Archiwum Narodowemu w Krakowie przez Cech Rzemiosł Różnych Księgi cechowej, zawierającej m.in. wpisy uczniów, zapisy dłużne, poręczenia, sprawy sporne Cechu piekarzy w Krakowie z lat 1440-1628. Pozycja ta stanowi wspaniałe uzupełnienie zgormadzonych już w zasobie akt cechowych.

W roku jubileuszowym podjęto szereg działań informacyjnych i popularyzatorskich umożliwiających szersze dotarcie użytkowników do oferty Archiwum w internecie. W kwietniu 2019 r. uruchomiono nową odsłonę strony internetowej www.ank.gov.pl, w warstwie wizualnej i architekturze informacji nawiązującej do portali w domenie gov. pl. W celu dostosowania serwisu internetowego Archiwum Narodowego w Krakowie do kryteriów dostępności cyfrowej WCAG 2.1. przygotowano również portal do prezentacji wystaw wirtualnych - www.archiwalneopowiesci.gov.pl. W ramach serwisu ank.gov. pl opublikowano jedenaście nowych galerii i wystaw internetowych (przygotowanych przez dr Barbarę Berską, Lidię Kowarsch oraz stażystów zdobywających zawodowe szlify w krakowskim Archiwum). Cieszący się dużą popularnością edukacyjny portal do nauki paleografii i neografii „Dawne pismo”, jak co roku został uzupełniony o nowe treści, gry i zabawy edukacyjne. Działalność popularyzatorską Archiwum wspierają social media: strona na Facebook-u (11 414 fanów i 11990 obserwujących) oraz kanał Archiwum Narodowego w Krakowie na YouTube (ponad 22289 wyświetleń w 2019 r.).

W 2019 r. ukazało się również pięć publikacji książkowych wydanych samodzielnie lub dzięki współpracy wydawniczej krakowskiego Archiwum. Oprócz wspomnianej monografii dotyczącej Bieżanowa autorstwa Tomasza Wrońskiego wydano pod redakcją dr Kamili Follprecht 24. tom „Krakowskiego Rocznika Archiwalnego” oraz katalog do wystawy „650 lecie herbu miasta Krakowa” (Bożena Lesiak-Przybył, Aldona Warzecha, dr hab. prof. UJ Zenon Piech). Edycja źródłowa Najdawniejszych ksiag grodzkich krakowskich z lat 1406-1409 przechowywanych w zasobie Oddziału I ANK, przygotowana przez Wiesława Filipczyka przy współpracy dr. hab. Macieja Zdanka i dr. Franciszka Sikory, ukazała się nakładem Archiwum oraz Instytutu Historii im. Tadeusza Manteuffla Polskiej Akademii Nauk w Warszawie i Polskiej Akademii Umiejętności w Krakowie. Swoją premierę miała również wydana przez Naczelną Dyrekcję Archiwów Państwowych i Archiwum Narodowe w Krakowie publikacja O miłości Ojczyzny nie deklamowaliśmy...: Wspomnienia Antoniego Sejmeja Górszczyka w opracowaniu Sylwestra Rękasa.

Lilianna Pochwalska Archiwum Narodowe w Krakowie 